\title{
PRODUCTION, REPRODUCTION OF ACEH AND PESISIR COWS IN INDONESIA: PAPER
}

\author{
LAODE MUH MUNADI \\ POSTGRADUATE AGRICULTURAL SCIENCES HALU OLEO UNIVERSITY \\ Email: Immunadi@gmail.com
}

\section{CHAPTER I \\ INTRODUCTION}

Farm production system is divided into two types, namely traditional and modern system. The pattern of livestock production system can be done with agricultural efforts are expected to give positive results with increased production. The development of beef cattle farming sector is felt to be increasingly important and has a strategic role. Acceleration of the strengthening of the scale of beef cattle farming business is required financing scheme as it is known to greatly spur the acceleration of the real sector so that it will increase the population of beef cattle and create economic empowerment of rural communities. Increased productivity of beef cattle requires an assessment of the characteristics of production systems based on local resources.

The development of such systems has the potential by implementing various systems to increase the added value of products. Production systems in Indonesia are generally classified into three categories, namely, limited land, crop-based cultivation and land-based grazing. Farms have a strategic role and function for smallholder businesses. Livestock can turn low-quality products into high-quality products such as meat and eggs, control weed growth, and provide nutrients to improve soil fertility such as fertilizer. Beef cattle maintenance systems in grazing land-based areas in Indonesia apply extensive, intensive and semi-intensive patterns are very common.

The germplasm of local Acehnese cows and pesisir cows has long played an important role for rural communities and has taken root in the good life in terms of economic, social and cultural communities. Aceh beef is a type of small beef cattle has contributed to the fulfillment of meat needs while pesisir cows also play an important role in the provision of meat for the community. These two types of local cattle have important meanings as economic and social values that are quite significant for the local community. Acehnese cows and pesisir cows have several advantages such as aceh cows have advantages such as adaptation to low-quality feed, have resistance to diseases and parasites and tame temperament. as well as aceh cattle have advantages including a source of local germplasm, good tropical environmental adaptation power, low quality feed adaptation power, relatively resistant to internal and external parasites, and good productivity.

This paper tries to review the production of the two local cattle nations to accelerate the increase in production. So far, there is still little information about the performance of production in aceh cattle and pesisir cows, based on the previous description the author is interested in reviewing aceh cattle production system and coastal cows as well as their development strategies. This is done for further development, so that the germplasm of Aceh cattle and pesisir cows can be preserved and needs to be bred which is the wealth of the Indonesian state. 


\section{CHAPTER II \\ PAPER DISCUSSION}

\subsection{Aceh Cattle}

Aceh cattle as a genetic resource that must be bred for the provision of seedlings in the future. Acehnese cows are a type of beef cattle and work. The maintenance system is traditionally carried out by rural farmers in aceh province. Acehnese cows have good environmental adaptability. Aceh cattle have low productivity compared to sub-tropical cows, but aceh cows have the advantage in adjusting to the severe natural pressures of tropical climate, poor feed conditions and resistant to parasitic attacks.

\subsubsection{Aceh Cattle Production Performance}

Aceh cattle production performance includes body weight and body size as well as Daily Weight Gain (PBBH) pre sapih and post sapih. According to Ikhsanuddin et al., (2018) bulls have a birth weight of $13.66 \pm 1.08 \mathrm{~kg}$, a weight of 205 days $71.60 \pm 7.92 \mathrm{~kg}$ and an age weight of 365 days $104.66 \pm 11.72 \mathrm{~kg}$. Heifers have a birth weight of $13.88 \pm 1.32 \mathrm{~kg}$, an age weight of 205 days $64.38 \pm 10.36 \mathrm{~kg}$ and an age weight of 365 days $90.29 \pm 11.95 \mathrm{~kg}$. One-day-old Acehnese cows have chest circumference, body length and shoulder height of $55.41 \mathrm{~cm}, 46.16 \mathrm{~cm}$ and $55.22 \mathrm{~cm}$ in bulls and $55.87 \mathrm{~cm}, 46.83 \mathrm{~cm}$, and $55.74 \mathrm{~cm}$ in heifers. Aceh cows aged 365 days have a size of chest circumference, body length and shoulder height respectively $114.32 \mathrm{~cm}, 94.31 \mathrm{~cm}$ and $92.93 \mathrm{~cm}$ in bulls and $104.25 \mathrm{~cm}, 85.06$ and $87.71 \mathrm{~cm}$ in heifers. While Jamaliah and Marwan (2018) that the average body weight of aceh cattle one year old reached $90.64 \mathrm{~kg}$. The average oneyear body weight of aceh cows is still low compared to bali cows. Bali cattle have an average one-year weight of $142.45 \pm 3.25 \mathrm{~kg}$ (Gunawan and Jakaria, 2011).

The body size of aceh cattle one day is lower than madura cattle reported by Sulistiyoningtiyas et al., (2017) that the body size of Madura cows average shoulder height $64 \pm 4.16 \mathrm{~cm}$, body length $52 \pm 6.25 \mathrm{~cm}$ and chest circumference $59 \pm 4.99 \mathrm{~cm}$. Abdullah et al., (2006) explained that the growth of aceh cattle a year old has an average body size of shoulder height of $93.77 \pm 5.82 \mathrm{~cm}$, body length of $93.42 \pm 8.03 \mathrm{~cm}$ and chest circumference of $118.65 \pm 8.30 \mathrm{~cm}$.

The body size of aceh cattle is one year lower than that of madura cows, as reported by Nurgiartiningsih (2010) that the body size of madura bulls at the age of one year has chest circumference, body length and shoulder height respectively $124 \mathrm{~cm}$, 101.3 and $108.9 \mathrm{~cm}$. Aceh cattle production performance is lower than other local Indonesian cows (Bali cattle, Madura and PO cows). This difference characterizes the identity of each livestock nation. Each breed of cow has different genetic traits from qualitative and quantitative properties. According to Soeharsono (2010) explained that the performance of the production of a livestock is the result of interaction between the environment and genetics that are often measured by weight gain and body size. So it is clear that each type of livestock has a structured production capacity that is derived from its elders.

\subsubsection{Aceh Cattle Reproduction Performance}

The problem faced by farmers is the low reproductive efficiency in livestock. This low reproductive efficiency can be caused by the lack of knowledge of farmers on the importance of reproductive regulation in the farm business. According to Novita et al., (2018) that aceh cattle reproductive performance is good, puberty reaches 1-2 years old, the average value of service per conception is 1.5 and the distance of lambing is 12.97 months. Eriani et al., (2015) that the first, second and third ejaculations in a row, 
the concentration of spermatozoa is $1,247.00 \pm 96.67 \times 106 / \mathrm{ml} ; 1,194.00 \pm 52.25 \times 106 / \mathrm{ml}$ and $967.60 \pm 63.71 \times 106 / \mathrm{ml}$. The percentage of live spermatozoa was $90.54 \pm 2.31 \%$, $90.20 \pm 1.91 \%$ and $73.87 \pm 2.33 \%$. The percentage of abnormal spermatozoa was $8.54 \pm 0.71 \%, 9.18 \pm 0.98 \%$ and $13.27 \pm 0.62 \%$.

Mukhlis et al., (2017) revealed that the average percentage of spermatozoa motility of aceh cows is $85.45 \pm 1.84 \%$ with a range between $84.00 \%$ to $88.00 \%$. is primary data taken directly from inseminators and breeders. conception rate in highland areas $64.77 \%$ and lowland areas $56.56 \%$ aceh cattle showed a noticeable difference ( $\mathrm{P}<0.05$ ) (Subagyo and Jakfar, 2020). Reproductive characteristics at the first birth of aceh cattle at the age of 2.6-3 years, with calving intervals of 14 months and weaning pedet average age 6 months (Makmur et al., 2020). But the difference in reproductive characteristics of female Aceh cows in Gayo Lues Regency is still not good. Aceh cattle females in Terangun subdistrict are sex adults at an average age of $14.3 \pm 1.26$ months, the first mating age at $23.9 \pm 3.42$ months, the distance of lambing $14.0 \pm 2.23$ months, the cow remarriage after lambing is $3.1 \pm 1.09$ months, and weaning pedet at the age of $4.5 \pm 0.54$ months (Basri et al., 2019).

Problems of low reproductive efficiency often occur in beef cattle. Low reproductive efficiency in beef cattle indicates the occurrence of reproductive disorders, one of which is repeat breeder. Repeat breeder is a female cow that has a normal cycle and has been mated at least three times with males or fertile male semen but has not bunting without accompanied by clinical symptoms of disease or abnormality of reproductive devices. Cows that experience repeated mating are generally characterized by long calving intervals (18-24 months), low coestption rates $(<40 \%)$, and high service per conception ( $>3$ ). The importance of knowledge of estrus in cows affects the success of reproductive management. Breeders who know about estrus well can estimate the next estrus, so that estrus observations can be done more intensively and the mating time is more precise (Subagyo et al., 2018).

Adult genitalia in female aceh cows occur at the age of 18 months. The average Service per Conception (S/C) of Aceh cows is 1.6. An S/C value of 1.6 is a good S/C number. Normal S/C values in cattle range from 1.6 to 2.0 (Affandi,2003). When compared to the S/C numbers of other cows, PO and Peranakan Limousine cows as reported by Nuryadi and Wahjuningsih (2011), each has S/C numbers of 1.28 and 1.34, so these two numbers are lower compared to S/C in Aceh cattle. Madura cows produced by Wijono and Setiadi (2004), Madura cows have a larger S/C of 1.7- 2.0. Bali cows have an S/C of 1.41 (Panjaitan et al., 2003), which indicates a lower number than Acehnese cows. According to Nuryadi and Wahjuningsih (2011), if S/C is low, then the fertility value of the heifer is higher and if the $S / C$ value is high, the lower the fertility rate. The average distance of calving interval of Aceh cattle shows 13.5 months with a range of 12-15 months. In general, farmers who keep female Aceh cows that have a 14-month child range of $40 \%$ (Makmur et al., 2020).

\subsubsection{Aceh Cattle Maintenance System}

Aceh cows have poor environmental resistance such as feed crisis, water, highfiber feed, parasitic diseases, hot temperatures and traditional extensive maintenance systems (Mirza and Rahayu, 2017). However, in contrast to research conducted by Herry et al., (2017) The size of the chest circumference of aceh cattle in the age of sapih maintained by intensive system shows a higher size compared to the size of the chest circumference maintained by the extensive maintenance system and on the measurement of body length and height of aceh cow gumba which is maintained with an 
extensive system shows a higher size compared to the size of the length and height of gumba in mop with an intensive system.

Aceh cow maintenance system still needs to be improved combined with a better management system (Widyaningrum et al., 2021). Management of warehousing with a semi-intensive system can arrange livestock well so that in the morning to afternoon cattle are released into grazing fields by eating natural grass and field grass, then cattle in the afternoon return to the cage (Mirza and Rahayu, 2017). According to Gunawan (1998), aceh cows are able to adapt to bad environments with traditional extensive maintenance systems.

\subsection{Pesisir Cattle}

Pesisir cows are native cows including five germplasms of cows native to Indonesia after bali cows, aceh cows, sumbawa cows, and madura cows. The superior properties of these coastal cows have been utilized to meet the needs of animal proteins in the community.

\subsubsection{Pesisir Cattle Production Performance}

Characteristics of pesisir cows have a small body weight, short body, slender legs, small humps, and tame. Bulls have short heads, short and large necks, wide neck backs, and large humps. The heifer has a rather long and thin head, oblique, short and thin (Saladin 1983). Adult bulls weigh $160 \mathrm{~kg}$, lower than bali cattle (310 kg) and madura cows (248 kg) (Adrial, 2010). However, coastal cows are highly productive, with high birth rates and adaptability in coastal environments.

According to Rusfidra (2007), pesisir cows have a relatively small body weight is the description of a nation of cows, so it can be stated that pesisir cows are typical cows of Indonesia and is a national genetic resource (germplasm) that needs to be developed and preserved. The birth weight of pesisir cows is an average of 14-15 kg /head. Pesisir cattle have an average daily weight gain from birth to sapih of about $0.32 \mathrm{~kg} /$ day, off sapih until age 2 years $0.21 \mathrm{~kg} /$ tail/day, and age $3-4$ years $0.12 \mathrm{~kg} /$ day. Weight gain from birth to sapih in heifers is $0.26 \mathrm{~kg} / \mathrm{day}$, loose sapih until the age of 2 years averages $0.19 \mathrm{~kg} /$ day, and age 3-4 years average $0.12 \mathrm{~kg} /$ day (Saladin 1983). According to Saladin (1983), the percentage of pesisir cow carcasses is $50.6 \%$, higher than the percentage of Ongole cattle carcasses (48.8\%), Madura cattle (47.2\%), PO cows (45\%) and buffalo (39.3\%), but slightly lower than the percentage of Bali cow carcasses (56.9\%).

Zahara et al., (2018) that the average length of the body of a male pesisir cow in Lengayang subdistrict aged 12-24 months $87.7 \mathrm{~cm}$; females $12-24$ months $88.3 \mathrm{~cm}$; females aged 36-48 months $86.6 \mathrm{~cm}$; Average length of the body of a male pesisir cow in Padang Mengatas age 12-24 months $100.2 \mathrm{~cm}$; females $12-24$ months $100.9 \mathrm{~cm}$; females aged 36-48 months $103.4 \mathrm{~cm}$; Average chest circumference of male pesisir cows in Lengayang subdistrict aged 12-24 months $102.2 \mathrm{~cm}$; females $12-24$ months $108.6 \mathrm{~cm}$; females aged 36-48 months $116.8 \mathrm{~cm}$; Average chest circumference of male pesisir cows in the field aged 12-24 months $133.1 \mathrm{~cm}$; females 12-24 months $120.7 \mathrm{~cm}$; females aged 36-48 months $143.9 \mathrm{~cm}$; Average shoulder height of male pesisir cows in Lengayang subdistrict aged 12-24 months $89 \mathrm{~cm}$; females $12-24$ months ,91 cm; females aged 36-48 months $96.9 \mathrm{~cm}$; Average shoulder height of male coastal cows in the field aged 12-24 months $100.1 \mathrm{~cm}$; females $12-24$ months $100.7 \mathrm{~cm}$; females aged 36-48 months 109.8 $\mathrm{cm}$. even the heat resistance of coastal cattle (95.86) is higher than that of the Peranakan Simmental cattle nation (92.94) and the Peranakan Ongole cattle nation (87.54) in the lowlands/pesisir (Nawaan, 2006). 
The appearance of pesisir cattle production in 1980 reached $275 \mathrm{~kg}$ and decreased to 225-250 kg in 2005, while for heifers decreased from 256 to $172 \mathrm{~kg}$. However, now the weight can not be found anymore because the condition of cattle has decreased considerably. This is thought to be due to natural resource conditions that are no longer able to support livestock growth and can only meet minimal needs. The weight gain of adult bulls is only $15 \mathrm{~g} /$ day, calves released until the age of 1 year 20 g/day, and cows aged 1.5-2.5 years and brood age 3-4 years old $140 \mathrm{~g}$ and $225 \mathrm{~g} /$ day respectively. This resulted in most pesisir cows being marketed before reaching maximum slaughter weight (Hendri, 2013).

\subsubsection{Pesisir Cow Reproduction Performance}

Problems in improving the physical and genetic performance of pesisir cows include the reproductive system. According to Yendraliza, (2005) The first mating average pesisir cow was 268.73 , the old bunting average was 277.39 , the average birth distance was 545.12, and the calving rate of pesisir cows was 26.93. Efforts to improve genetic quality are carried out through selection followed by the mating system by utilizing reproductive technology. The problem in the reproductive system of pesisir cows is the lack of availability of superior males so that the males who are used as checkers are young cows that are $<2$ years old. To solve the problem, it is necessary to regulate the production of male livestock from the population and selection of males who have superior properties to be used as a checker. Cross breeding with cattle (Asmairicen, 2014).

The results of Sulin research (2008) showed that improved reproductive management through artificial insemination (IB) between pesisir cows and superior cows was able to improve the production and reproduction performance of pesisir cows. Increased productivity is pursued through the provision of quality males, improving the performance of the mother and mating system, providing adequate feed, and adequate maintenance management.

Ichsan et al., (2020) reproductive properties of female cows F1 crossing Bali pesisir $\times$ such as calving interval $14.04 \pm 1.44$ months and Service period $151.03 \pm 21.43$ days. This falls into the still less good category. Furthermore, the value of Service per Conception in pesisir $\times$ Bali cows is $1.2 \pm 0.42$. Thus the value of Service per Conception in female cows crossing Bali $\times$ pesisir at the survey site falls into the ideal category.

\subsubsection{Pesisir Cow Maintenance System}

Improved maintenance management has the opportunity to spur increased productivity and pesisir cow populations. Arzil (2000) reported that the body size of semi-intensively reared pesisir cows is greater than that of traditionally raised cows. Susilawati et al., (2005) reported that the application of integrated farming technology at the ups and downs can increase the daily weight gain of cows by 37 $\mathrm{kg} /$ tail/maintenance cycle. Similarly, Zahara et al., (2018) revealed differently that coastal cattle production performances maintained with intensive patterns (grazing fields) are better than the umbar system (traditional).

Pesisir cattle maintenance system has been maintained by grazing in the pasture throughout the day without control from farmers, both in terms of quality and quantity of feed and mating cattle in grazing fields. Mating occurs naturally in grazing fields without male arrangement (Wahyuni and Dewi, 2018). Therefore, it is necessary to make improvements to feed and management of pesisir cow maintenance. 


\subsection{Aceh Cattle and Pesisir Cattle Development Strategy}

Identification and strategy of development of farm areas so that the area of farms that have developed in the area can be optimized for utilization, so as to foster new investments for beef cattle cultivation (Mayulu and Suhardi, 2016). Similarly, land as an ecological base supporting feed and livestock cultivation environment should be optimized for the development of livestock areas (Saputra, 2016). Interventional factors approach through improved livestock production system through improved livestock production system through improvement of feeding, breeding and good farming practice aspects need to be implemented and reviewed.

\subsubsection{Genetic Purification}

The genetic diversity of local livestock needs to be maintained for the purpose of selecting or utilizing certain genes to obtain the desired productivity (Istiqomah, 2006). Therefore, maintaining genetic diversity through conservation is important, both scientifically and socio-economicly (Adrial, 2010). The genetic purity of pesisir cows and aceh cows needs to be maintained as germplasm reserves for future development of farms without compromising the chance of improving their genetic quality, through the determination of special areas for the genetic purification of pesisir and aceh cattle.

\subsubsection{Genetic Quality Improvement}

Uncontrolled or overly restrictive mating patterns can lead to erosion of genetic material (Yendraliza, 2005). Efforts to improve genetic quality are carried out through selection followed by the mating system by utilizing reproductive technology (Kusriatmi et al., 2016). The problem in the reproductive system of pesisir cows and aceh cows is the lack of availability of superior males so that the males who are used as checkers are young cows that are $<2$ years old. To solve the problem, it is necessary to regulate the production of male livestock from the population and selection of males that have superior properties to be used as a checker (Sulin, 2017).

Cross breeding with a superior cattle nation needs to be done to increase the productivity and reproduction of pesisir cows and aceh cows without damaging their genetic purity. Improving the genetic quality of aceh and pesisir cows aims to increase body weight, growth rate, and reproductive efficiency through selection. Increased productivity is pursued through the provision of quality males, improving the performance of the mother and mating system, providing adequate feed, and adequate maintenance management.

\subsubsection{Restrictions on Livestock Expenditure}

High market demand and the insistence on living needs lead to high levels of livestock production from the population, especially high-productivity livestock, so that the remaining livestock have a low productivity performance on average (Ikhsanuddin et al., 2018). If this condition is not resolved in the next few generations, it is feared that there will be a decrease in livestock productivity (Ikhsanuddin et al., 2018). Solving this problem should involve various parties, such as the Livestock Service, universities, research institutes, local governments, associations, traders, and breeders. Enforcement of government regulations accompanied by supervision and awareness raising of various related parties needs to be developed to preserve and increase the productivity of pesisir cows and aceh cows. Government efforts through the Livestock Service that regulate livestock expenditure, especially productive livestock are expected to inhibit the rate of genetic quality decline of coastal cattle. 


\subsubsection{Maintenance Management Improvements}

Improved maintenance management has the opportunity to spur increased productivity and populations of pesisir cattle and aceh cattle. The body size of semiintensively maintained pesisir cows is greater than that of traditionally raised cows. The application of integrated farming technology in tidal land can increase the daily weight gain of cows by $37 \mathrm{~kg} /$ tail/maintenance cycle. The maintenance of pesisir cattle on people's farms provides a better income than cattle businesses conducted through mating with IB (Eriani et al., 2015).

In order for pesisir cattle farming businesses to increase farmers' incomes, a cultivation approach is needed through a sustainable production system. Sustainable production system can be applied at the farmer level with a maintenance scale of 4-6 cows consisting of 2-3 adult bulls for fattening and 2-3 adult heifers for breeding. Fattening cows can be sold at any time to meet the needs, while the heifers remain sustainable as seedlings. Cultivation technology to increase coastal cattle productivity includes the implementation of integrated livestock business management through:

1. Selection of seedlings or superior candidates based on age, physical characteristics, hereditary history, and health.

2. Warehousing management with standard cage technology.

3. Feed management through the introduction of superior forage, utilization of local feed ingredients and agricultural product follow-up products, crop-livestock integration system, and balanced ration technology based on low external input sustainable agriculture (LEISA).

4. Reproductive management by selecting broods and males, preventing inbreeding, and applying IB technology.

5. Prevention and control of diseases periodically, especially infectious diseases, vaccinations, eradication of disease vectors, alerting field officers (veterinary medical personnel), as well as reporting disease events to local officers and livestock agencies.

\section{CHAPTER III CONCLUSION}

The results of the literature study presented in a paper on the production and reproduction system of aceh cows and pesisir cows as well as their development can be concluded as follows:

1. Local cattle production in Indonesia such as aceh cattle a year old has an average body size shoulder height of $93.77 \pm 5.82 \mathrm{~cm}$, body length of $93.42 \pm 8.03 \mathrm{~cm}$ and chest circumference reaches $118.65 \pm 8.30 \mathrm{~cm}$. also, the average percentage of motility of aceh cow spermatozoa is $85.45 \pm 1.84 \%$ with a range between $84.00 \%$ to $88.00 \%$.

2. The average daily production of weight gain from birth to sapih is about 0.32 $\mathrm{kg} /$ day and heifers $0.26 \mathrm{~kg} /$ day, cattle release up to the age of 2 years on average $0.19 \mathrm{~kg} / \mathrm{day}$, and age 3-4 years on average $0.12 \mathrm{~kg} /$ day with the first mating average 268.73 , the average length of bunting 277.39 , the average birth distance of 545.12, and calving rate of pesisir cows 26.93 .

3. Aceh cattle and pesisir cattle development strategy with genetic purification approach, genetic quality improvement, livestock expenditure restrictions, and maintenance management improvement. 


\section{DAFTAR PUSTAKA}

Adrial. 2010. Potensi Sapi Pesisir Dan Upaya Pengembangannya Di Sumatera Barat. Jurnal Penelitian Dan Pengembangan Pertanian, 29(2), 66-72.

Abdullah, M.A.N., R.R. Noor, H. Martojo, D.D. Solihin, dan E. Handiwirawan. 2006. Keragaman fenotipik sapi aceh di Nanggroe Aceh Darussalam. Journal of Indonesian Tropical Animal Agriculture 32(2), 11-21.

Affandhy. 2003. Kinerja Produksi dan Umur Pubertas Pedet Hasil Kawin Silang Sapi PO, Simmental, Sapi Aceh dan Limousin dalam Usaha Peternakan Rakyat. Pusat Penelitian dan Pengembangan Peternakan. Bogor

Asmairicen, S. 2014. Prospek Sapi Pesisir Sebagai Ternak Lokal Yang Menjanjikan. Balai Pengkajian Teknologii Pertanian Aceh, Hal. 1-14.

Basri, M. P., Abdullah, A. N., dan Asril, A. 2019. Evaluasi Karakteristik Reproduksi Sapi Aceh Betina Di Kecamatan Terangun Kabupaten Gayo Lues. Jurnal Ilmiah Mahasiswa Pertanian, 4(2), 247-256.

Eriani, K., Rahmiati, R., dan Dasrul, D. 2015. Kualitas Dan Morfologi Abnormal Spermatozoa Sapi Aceh Pada Berbagai Frekuensi Ejakulasi. Prosiding Seminar Nasional Biotik, 339-334.

Gunawan, A. dan Jakaria. 2011. Genetic and non-genetics effect on birth, weaning, and yearling weight of bali cattle. Media Peternakan 34(2):93- 98.

Hendri, Y. (2013). Dinamika Pengembangan Sapi Pesisir Sebagai Sapi Lokal Sumatera Barat. Jurnal Penelitian Dan Pengembangan Pertanian, 32(1), 39-45.

Herry, F., A, M. A. N., dan Asril, A. 2017. Evaluasi Ukuran Tubuh Turunan Sapi Aceh Dengan Sistem Pemeliharaan Berbeda Di Kecamatan Indrapuri, Aceh Besar. Jurnal Ilmiah Mahasiswa Pertanian, 2(4), 27-334.

Ichsan, A., Sarbaini, S., dan Fuad, M. 2020. Penampilan Reproduksi Sapi Betina F1 Persilangan Bali Dan Pesisir Di Kabupaten Padang Pariaman. Jurnal Ilmu Ternak, 20(2):95-101.

Ikhsanuddin, I., Nurgiartiningsih, V. M. A., Kuswati, K., dan Mukhtar, M. 2018. Penampilan Produksi Sapi Aceh Umur Satu Hari, Umur Sapih, Dan Umur Satu Tahun. Jurnal Ilmu Dan Teknologi Peternakan Tropis, 5(3), 67-72.

Ikhsanuddin, I., Nurgiartiningsih, V. M. A., Kuswati, K., dan Zainuddin, Z. 2018. Korelasi Ukuran Tubuh Terhadap Bobot Badan Sapi Aceh Umur Sapih Dan Umur Satu Tahun. Jurnal Agripet, 18(2), 117-122.

Istiqomah, L. 2006. Kemajuan Genetik Sapi Lokal Berdasarkan Seleksi Dan Perkawinan Terpilih. Balai Pengembangan Proses Dan Teknologi Kimia (BPPTK)-LIPI, 1(1), 63-67.

Jamaliah dan Marwan. 2018. Kajian kualitatif sapi aceh betina berdasarkan umur hasil uji performan pada Balai Pembibitan Ternak Unggul dan Hijauan Pakan Ternak Indrapuri.

Kusriatmi, Nfn, Oktaviani, R., Syaukat, Y., dan Said, A. 2016. Peranan Teknologi Inseminasi Buatan (IB) Pada Produksi Sapi Potong Di Indonesia. Jurnal Agro Ekonomi, 32(1), 57-74.

Makmur, A., Abdullah, M. A. N., dan Sari, E. M. 2020. Karakteristik Reproduksi Sapi Aceh Betina Di Kecamatan Pantan Cuaca Kabupaten Gayo Lues. Jurnal Peternakan Indonesia (Indonesian Journal Of Animal Science), 22(3), 306-312.

Mayulu, H., dan Suhardi, S. 2016. Potency And Carrying Capacity Of Rice Straw For Beef Cattle Feeding In East Kalimantan. Jurnal Ilmu Dan Teknologi Peternakan, 4(3), 119-129. 
Mirza, I., dan Rahayu, W. 2017. Model Pengembangan Kawasan Peternakan Sapi Aceh Di Kabupaten Aceh Jaya Propinsi Aceh. Jurnal Peternakan Indonesia (Indonesian Journal Of Animal Science), 19(3), 156-164.

Mukhlis, M., Dasrul, D., dan Sugito, S. 2017. Analisis Motilitas Spermatozoa Sapi Aceh Setelah Pembekuan Dalam Berbagai Konsentrasi Andromed®. Jurnal Agripet, 17(2), 112-120.

Nawaan, S. 2006. Daya Tahan Panas Pada Sapi Peranakan Simmental, Peranakan Ongole Dan Sapi Pesisir. Jurnal Peternakan Indonesia (Indonesian Journal Of Animal Science), 11(2), 158-166.

Novita, C. I., Sari, E. M., dan Rahma, E. 2018. Karakterisasi Penampilan Reproduksi Sapi Aceh Betina Sebagai Sumber Daya Genetik Ternak Lokal Di Kota Subulussalam. Jurnal Agripet, 18(1), 36-40.

Nurgiartiningsih, V.M.A. 2010. Sistem breeding dan performans hasil persilangan sapi madura di Madura. Jurnal Ternak Tropika, 11(2): 23-31.

Saputra, J. I. 2016. Analisis Potensi Pengembangan Peternakan Sapi Potong Di Kabupaten Pesawaran. Jurnal Ilmiah Peternakan Terpadu, 4(2), 115-123.

Soeharsono. 2010. Fisiologi Ternak tentang Fenomena dan Nomena Dasar, Fungsi dan Interaksi Organ pada Hewan. Widya Padjadjaran. Bandung.

Subagyo, D., dan Jakfar, M. 2020. Perbedaan Keberhasilan Inseminasi Buatan Pada Sapi Aceh Antara Daerah Dataran Tinggi Dan Daerah Dataran Rendah Di Kabupaten Pidie. Jurnal Sains Riset, 10(2), 105-113.

Subagyo, D., Siregar, T. N., Dasrul, T. R. F., dan Sabri, M. 2018. Pengetahuan Peternak Tentang Estrus Pada Sapi Aceh Dengan Terjadinya Repeat Breeding Di Kabupaten Pidie. Jurnal Agroristek, 1(1), 1-3.

Sulin, I. 2017. Identifikasi Performa Produksi Dan Service Periode Sapi Pesisir Dan Hasil Persilangan Inseminasi Buatan Di Kabupaten Pesisir Selatan Sumatera Barat. Jurnal Embrio, 1(1), 29-34.

Sulistiyoningtiyas, I., V.M.A. Nurgiartiningsih, dan G. Ciptadi. 2017. Evaluasi performa bobot badan dan statistik vital sapi madura berdasarkan tahun kelahiran. Jurnal Ilmiah Peternakan Terpadu, 5(2): 40-43.

Wahyuni, R., dan Dewi, R. A. 2018. Teknologi Tepat Guna Mendukung Pengembangan Sapi Lokal Pesisir Sumatera Barat. Jurnal Penelitian Dan Pengembangan Pertanian, 37(2), 49-58.

Widyaningrum, R., Budisatria, I. G. S., dan Maharani, D. 2021. Natural Increase, Net Replacement Rate, Output And Population Dynamic Of Aceh Cattle In Livestock Breeding And Forage Center Of Indrapuri. Journal of The Indonesian Tropical Animal Agriculture, 46(1), 1-11.

Yendraliza, Y. 2005. Performans Reproduksi Sapi Pesisir Dan Sapi Bali. Di Daerah Inseminasi Buatan Kecamatan Bayang Kabupaten Pesisir Selatan. Jurnal Peternakan, 2(1), 1-5.

Zahara, Y., Syafrizal, S., dan Irwandi, S. 2018. Analisis Komparatif Performan Produksi Sapi Pesisir Yang Dipelihara Pada Bptu Padang Mengatas Dengan Di Kecamatan Lengayang. Jurnal Embrio, 10(2), 15-23. 